\title{
UNEP scheme to bring power to Pakistan's villages
}

Although some of Pakistan's urban centres are based on those of affluent societies, $75 \%$ of its population, inhabiting 45,000 villages, still live in the 5,000 year-old Moenjodaro style. All but 6,000 of the villages are without electricity.

An experiment, based on studies made a couple of years ago for the United Nations Environment Programme (UNEP), however, could be a harbinger of change and bring improvements to the quality of life in rural Pakistan. Proposed by Dr I. H. Usmani, Energy Adviser to the United Nations Centre for Natural Resources, Energy and Transport in New York, the scheme is designed to harness solar energy, wind power and village bio-mass to generate electrical power on a suitable scale for a village of 100-150 families. These generating stations, to be called Rural Energy Centres (REC), will only use commercially available, proven technological devices.

Dr Usmani, who has been both Chairman of the Pakistan Atomic Energy Commission and Chairman of the Board of Directors of the International Atomic Energy Agency (IAEA), has ceased to be a nuclear enthusiast since he joined UNEP five years ago. During a recent visit to Pakistan he discussed his REC plan in some detail with General Zia-Ul-Haq, Chief Marshall Law Administrator.

The UN has agreed, in principle, to establish four RECs in Pakistan. The cost will be met from Pakistan's country programme quota and $\$ 800,000$ set aside for the purpose. Dr Usmani spent some of his visit finalising the project document for the four proposed units, one in each province of Pakistan. A fifth REC, however, may precede the UN-sponsored ones. Dr Usmani said that General Zia-U1-Haq was so pleased with the idea that he wanted one REC, financed by Pakistan's government, to be set up as soon as possible in a village near Rawalpindi. The UN-sponsored centres may take two or more years to become operational.

The UN is already establishing three RECs in three other third world continents. One is in Sri Lanka in Asia, one in Mexico in Latin America and the third in Senegal in Africa. All three are beyond the drawing board stage. Quotations have already been received for the Sri Lanka centre. It will cost between $\$ 300,000$ and $\$ 350,000$ and will generate $100-150 \mathrm{KW}$ of electrical power.

The design of individual RECs will be dependent on local geography and the local potential of renewable energy sources, especially solar, wind and water power and bio-mass. Bio-mass will be fermented to produce bio-gas and burnt to produce char and oil as solid fuel for cooking.

A typical REC will include:

- A solar-thermal device. This will use either low-grade heat to drive a freon turbine in a Rankine cycle engine

Sorry, for copyright
reasons some images
on this page may not
be available online

Village life: light on the way? generator producing about $10 \mathrm{KW}$; or high temperature steam to drive a conventional engine.

-A panel of solar photo-voltaic cells to produce $2 \mathrm{KW}$. This would give about $8 \mathrm{KW}$ per day on average.

- Two wind generators of 2-4 KW. $025 \mathrm{KW}$ capacity diesel generators modified to work on bio-gas.

-A long-life battery of lead-calciumantimony cells to store $150-300 \mathrm{KWh}$ (e) per day.

The electrical energy obtained could be used by 100 village familes to pump well water, light homes, schools and streets, irrigate 5-10 hectares per day, and supply a few small village industries.

Although the per $\mathrm{KW}$ cost of generating electricity in this way is expensive, Dr Usmani pointed out that there is really no other option. He thought that the present cost would fall because the cost of solar cells was bound to fall further. A decade ago, photo-voltaic cells cost about $\$ 150 / \mathrm{W}$ : now, they cost $\$ 15 / \mathrm{W}$ even when the total generated power does not exceed 10MW. If demand rises to $500 \mathrm{MW}$ the cost may come down to $\$ 1 / \mathrm{W}$, he said. The UN is helping to increase this demand by establishing RECs.

In any case, Dr Usmani said, it was not economically feasible to extend the grid to cover scattered far flung villages in countries like Pakistan. Neither, with the high cost of oil and coal, was it feasible to build oil or coal fired rural power stations for a cluster of remote villages.

Dr Usmani said that his economics for RECs "bear comparison even now, in terms of the cost of power per unit, with that produced by diesel power generators if the price of oil is 20 cents/litre or more and funding of rural electrification is available at a $2-5 \%$ rate of interest".

Azim Kidwai

increased by $3.4 \%$, most of the increase coming from the domestic users.

By the end of 1977, total nuclear capacity was $22,400 \mathrm{MW}$, an increase of $3,300 \mathrm{MW}$ on the previous year. In 1978 nuclear capacity should reach $27.000 \mathrm{MW}$ and contribute $12 \%$ of total energy compared to $10 \%$ in 1977 .

The report forecasts a $3 \%$ increase in energy demand in 1978. Oil demand is expected to increase by $2 \%$, natural gas by $9.9 \%$ and electricity by $3.9 \%$. Coal consumption should increase marginally. The GNP is expected to rise by about $3 \%$. The Community's annual, medium term target is $4.5-5 \%$.
The demand for oil fell by $2 \%$ in 1977 to 530 million tonnes. The report puts most of this down to reduced 250 million tonnes of oil equivalent, mainly because of depression in the steel industry and a reduction in the consumption of coke and coal. But more coal was used in power stations.

In contrast to this downward trend. natural gas consumption increased by $6 \%$. Its total share of energy supply rose to $17.5^{\prime \prime \prime}$, Electricity demand 